\title{
sciendo
}

DOI: $10.2478 /$ jolace-2021-0011

\section{Meaning equivalence issue of English and Lithuanian terms of finance}

\author{
Virginija Stankevičienė, Viorika Šestakova, \\ Daiva Zavistanavičienè \\ Kaunas University of Technology \\ virginija.stankeviciene@ktu.lt, viorika.sestakova@ktu.lt, \\ daiva.zavistanaviciene@ktu.lt
}

\begin{abstract}
The intensification of language contacts has led to increasing problems of compliance between terms in different languages in the translation of subject-specific texts. Dictionaries are the main tool in clarifying term meanings and trying to find the most appropriate version which could be perceived by the representatives of different languages equally. More accurate dissemination and usage of the term equivalent allows the addressee (recipient) to better comprehend the contents of the language. Not only are meaning explanation and consistency of definition formulation significant aspects in compiling bilingual dictionaries but also determination of term equivalents. Although terms of economics have old traditions in various languages, it is possible to notice the cases of meaning discrepancy and different perception. The choice and usage of appropriate term remain crucial in communicating about various finance-related operations. The more accurate and clearer the term the better perception of the subtleties of other language. The purpose of this article is to determine the extent to which the concepts of a semantic group representing finance are equivalent, i. e. how similar and different their features are in English and Lithuanian. The research revealed that the majority of the analysed terms are partially equivalent in both languages. Hence, partial equivalents and surrogates in particular may cause confusion and discrepancy in term meaning perception.
\end{abstract}

Key words: meaning, concept, terms of finance, economic terms, equivalence

\section{Introduction}

In the context of globalisation, a term that is properly used and correctly perceived has a great significance both in scientific and subject texts. Every language is unique and has its own requirements for content and expression (Keinys, 2005, p. 320). However, dissemination and usage of clearer, more accurate and precise means of communication allow the addressee (recipient) to better understand the content of the language. In translation and learning process, language dictionaries are a key tool for explaining the meanings of terms and trying to find the most appropriate option that would be equally understood by the representatives of various languages. The most important aspects in compiling bilingual dictionaries are the interpretation of meaning, the consistency of definition formulation as well as the determination of term equivalents. It is worth mentioning that most economic terms were coined a long time ago and have old traditions. Correctness of their use is in no doubt. However, along with social changes there are economic developments that enable the new ones to appear alongside the existing ones. The emergence of new economic terms often changes understanding and attitudes towards the existing terms and their definitions in dictionaries. Often the meaning of a term used in the media differs from that given in dictionaries. Naturally, as the language itself changes the definitions of word meanings transform as well. Yet, what works for a major lexical fund is not appropriate for terms. There is also the problem of relying solely on the meaning given in dictionaries and not trying to draw attention to the 
various perceptions and interpretations of certain subjects in different languages. This is particularly evident in practice, i. e. translating subject-related texts when a problem arises which term is more appropriate or clearer to the representative of another culture. Term dictionaries remain the main source for translating profession-oriented texts. Dictionaries are frequently published repeatedly after minor corrections and additions. However, distinct comprehensions and even explications of diverse language users are not taken into account choosing to use terms in both spoken and written texts.

Term polysemy has been analysed by Lithuanian linguists (Jakaitienè, Keinys, Gudavičius) as well as researchers of other languages (Nordisk, Sterkenburg, Jackson, Ze Amvela). In the context of language contacts, when developing new terms, it is utterly important that terms are understood equally by people who use different languages. This type of practical research is important in the field of machine translation, also for terminologists who newly publish dictionaries where the introduction of term meanings can be refined considering comments and observations. Although terms of economics have long traditions in languages, there are many cases of diverse perceptions and mismatch of meanings. Maskaliūnienè (2015) emphasizes that words of the general language used in the texts of all fields are characterized by polysemy, due to which it is extremely difficult to choose the appropriate word in a specific context. According to her, the aim for machine translation programs should be focused on ability to translate terms as accurately as possible and to find their equivalents, provided that the terms do not have the polysemy feature.

The use of the proper term is also crucial for various financial transactions because the more precise and clearer the term, the better the understanding of the subtleties of one language or the other. Moreover, business success or failure is greatly affected by the proper usage of terms. Thus, both the expression of the term and the issues of term perception in various cultures remain relevant to all people who are involved with searching, determining and translating terms in order to find the most accurate option with the same meaning. Dictionary compilers should not stand behind the rapid development of economic terminology and record it in dictionaries (Tadauskiené, 2004, p. 61). Not only is the number of meanings of the same term provided in language dictionaries different but also the interpretation of the same terms is not the same. This causes confusion in the practical use of dictionaries and in the proper understanding / selection of terms in special terminology, and their application in profession-oriented language or other subject-related texts.

The aim of this research is to determine to what extent the concepts of economic term group related to finance are equivalent, i. e. how similar and different their properties are in English and Lithuanian. In order to achieve the set goal, the following tasks were put forward: to analyse the scientific literature on the chosen topic; to determine the degree of equivalence of the economic group associated to finance; to analyse the similarities and differences of the terms ascribed to finance. The following scientific methods were employed in the research: analysis of scientific literature; comparative interlingual method that helps to reveal general and specific features of English and Lithuanian. The object of the research is the terms of the semantic group defining finance, the concepts denoted by them in English and Lithuanian languages.

Not only are dictionaries a means of capturing data about a language but they are also essential in finding out the level and peculiarity of society's cognition of the world (Jakaitienè, 2005, p. 11). In recent years, only few dictionaries of economic terms were published in Lithuanian. The ones to be mentioned are as follow: Pearce's Aiškinamasis ekonomikos anglų - lietuvių kalbų žodynas (2006, Explanatory English Lithuanian 
Dictionary of Economics), Vainienè's Ekonomikos terminu žodynas (2005, Dictionary of Economic Terms), and Aiškinamasis įmonés vadybos terminu žodynas (2000, Explanatory Dictionary of Management Terms) by Martinkus, Neverauskas, et al.

With reference to the comments of terminologists on published dictionaries, the research material in this work is based on Vainienè's Dictionary of Economic Terms (2005) and Longman Dictionary of Business English (1-e-DIC). In order to find out similarities, as well as what is typical for English and Lithuanian economic terms related to finance, the chosen terms are divided into the following groups: 1) surrogate equivalents; 2) partial equivalents; 3) absolute equivalents.

\section{Theoretical background}

In today's information society, dictionaries play a unique role in translating subjectrelated texts. The study of the semantics of descriptive lexical units in dictionaries is particularly important as it relates to the most significant function of the dictionary; users in the dictionary usually search for information what a certain word means (Jackson 2002). Reviewing theoretical material on dictionaries, their editions and approbation in Lithuania, it can be stated that tremendous work has been done both in printed and electronic forms. Most dictionaries are transferred to the electronic database and can be used in the Term Bank of the Republic of Lithuania. Electronic terminography makes it possible to coordinate concepts of different languages, in other words, to standardize terms.

Nordisk accentuates so that to ensure profession-oriented communication, which is equally understood by all, the science of language employs terminology, the functionality of terms in a language (Nordisk, 1997, p. 253). However, in order for such communication to be as reliable and complete as possible, terminology must be precise and meet the requirements specified for terms. The term must be lexically, morphologically, syntactically, and phonologically correct (Terminologijos vadovélis Europos Komisijos vertimo raštu Generalinio direktorato Lietuvių kalbos departamento vertejjams, 2006, p. 2).

In theoretical works, which provide guidelines on term coinage techniques, the basic requirement is that the term be assigned to only one concept, and that this particular concept be conveyed by only one term. In scientific literature, this is defined by the term monosemy and it is the focus of dictionary compilers (Jakaitienè, 2005, p. 191, Falkum 2015). Monosemous terms do not leave the language user or researcher in doubt. Yet looking at any term entry the dictionary shows that in addition to monosemous terms, they contain terms that have a connection to two, three, or more denotations and often mean more than one concept. Such a phenomenon, when a word can have more than one meaning, is called polysemy in the scientific literature (Gr. poly 'many' and sēmasia 'meaning'). Polysemy is defined as 'the relationship between designations and concepts in a single language, where a single designation indicates two or more concepts with certain common properties (LST ISO 1087-1:2005; Falcum, 2015; Vogel, 2008). Polysemy is a complex and controversial issue, as it is difficult not only to separate the meanings of words from each other, but also to define them, to determine their boundaries and numbers (Jakaitienè, 2010, p. 87; Jackson, 2002, p. 89; Jackson \& Ze Amvela, 2014, p. 67). These cases hinder the purposeful transmission of information and communication.

The fact that dictionaries contain dissimilar number of meanings of the same word depends both on various goals and scope of dictionaries, as well as the nominative function (or purpose) of a word. Theoretical literature states that issues of the meaning of a word are discussed by specialists of several fields. Thus, the meaning of a word is 
equally important to the psychologist, the philosopher, and the linguist (Jakaitienè, 2005, p. 79).

In Lithuanian, the main meaning of the word is considered to be the most significant, where only a single word is perceived as a representative of the main meaning (Jakaitiene, 2010 , p. 90). It neither completely depends on the context nor position in various sentences. In explanatory dictionaries, according to the researcher, the main meaning of a word is given first, as it usually determines the emergence of other meanings of the word. The secondary meaning depends on the place of the word in the sentence, it occurs and is understood when the word is used in a particular context. For this reason, linguists also call this meaning a bound meaning (Jakaitienè, 2010, p. 90). Figurative meanings are metaphorical and metonymic. Furthermore, Jakaitienè points out that a metaphorical meaning is formed if a word naming one thing is replaced by a word nominating another due to the similarity of those things. If the reason for the word transfer is a logical connection of the named things, the resulting value is metonymic. Figurative meaning becomes a constant meaning only when it takes root in usage and is understood by the majority of speakers (Jakaitienè, 2010, p. 91). Jackson and Ze Amvela (2014, p. 69) agree in stating that the word has direct and figurative meanings derived from the direct one but the total number of meanings of the word cannot be determined.

Discussing the types of meanings of polysemous terms, van Sterkenburg (2003, p. 86) specifies that in the process of determining which individual word meanings have to be included into a dictionary should be based on general relationship between a word meaning and world perception, as well as conceptual definition of objects. Moreover, it is crucial to decide what type meanings will be defined and specified in a dictionary. However, when a word is polysemous, it is not easy to decide what meanings will be included. As emphasized by van Sterkenburg (2003, p. 85), these meanings are interrelated and dictionary compilers may try to point out these connections directly. The connections of meaning exist between the words themselves and are linked onomasiologically, whereas the connections of meaning within the word itself are connected semasiologically. Although, one must keep in mind that successful communication can only be achieved if terminology is understood by both parties. Buhlmann (2000) states that the purpose of terminology is to define things and phenomena of a certain field precisely and clearly (Buhlmann, 2000, p. 33).

Meanings and words are the main juxtaposition aspects of comparative semantics. Comparative studies are increasingly focusing on the functioning of different language equivalents. Generally, words in various languages have a peculiar semantic structure. Yet, it happens that the main word in its entire semantic structure (in one or all meanings) coincides with the semantics of the equivalent. However, there are a great many terms where semantic connections to words in another language are very complex (Jakaitienè, 2005 , p. 151). If the connections of equivalent words in different languages do not match, then the associations in those languages are also distinct (Gudavičius, 2007, p. 220). When comparing languages, the semas of their meanings need to be compared because only then the difference in those meanings is understood (Gudavičius, 2007, p. 23). Gudavičius (2007) states that equivalence is the sememes that are close in content to their meanings and are used as equivalents in translating texts from one language to another (Gudavičius, 2007, p. 68). According to Kontutyte (2008), comparative terminology considers a concept as a basis for comparison but concepts in different languages do not always have similar properties as concepts have changed and evolved in dissimilar contexts. Therefore, such concepts may not have similar features and may have completely diverse positions in language concept systems (Kontutyté, 2008, p. 70). Arntz, Picht and Mayer 
(2004, p. 152) argue that terms are equivalent only when the concepts of those terms are identical. Armalytė and Pažūsis (1990, p. 57) state that equivalence is a relationship between two units having the same value and meaning. In order to determine whether the concepts are equivalent, it is necessary to compare them and their properties (Kontutyte, 2008, p. 70). When discussing the terms of the semantic group defining finance, the classification and research of the authors discussed above are used.

\section{Analysis and discussion}

For the research, 104 economic terms denoting finance were selected. From the chosen terms, 26 of them were not defined in Longman Dictionary of Business English. Consequently, the study sample is based on the 78 economic terms defining finance which were explained in the aforementioned dictionary. The selected terms were analysed according to the classification of Svensen (1987, p. 134-141 in Jakaitienè, 2005) which distinguishes three main groups of equivalence:

1) surrogate equivalents. This is the phenomenon when the concept of the word in original language is paraphrased or explained in the second language;

2) partial equivalents. In this context, the meaning of the word is partially explained;

3) absolute equivalents. In this case, the meaning of the word coincides with the second language meaning completely.

The terms were also analysed, compared and discussed using the method based on Arntz, Picht and Mayer's statements, which claim that terms are considered to be equivalent if their concept properties coincide (Kontutytè, 2008).

Having studied the terms denoting finance, surrogate terms whose concept properties in English and Lithuanian languages did not coincide made up 21\% of the studied sample. $42 \%$ of the terms correspond to partial equivalents and $37 \%$ of the analysed terms are assigned to the group of absolute equivalents.

In the text, letter $\mathbf{A}$ is used to indicate the target language - English, letter $\mathbf{B}$ nominates the source language, i. e. Lithuanian.

\section{Surrogate equivalents. Concept properties do not coincide $(A \neq B)$}

The first group of the studied terms covers cases of surrogate equivalence. A term is considered to be surrogate if the word concept in the original language is paraphrased in the second language or the term concept conveys a different meaning. 21\% of surrogate equivalence were identified in the analysed sample. Examples included in that group are as follow: Eng. franchise tax / Lith. franšizés mokestis (ETŽ 94), Eng. net value / Lith. grynoji vertė (ETŽ 101), Eng. cash balance / Lith. grynuju pinigų atsarga (ETŽ 101), Eng. gross profit / Lith. bendrasis pelnas (ETŽ 43), Eng. mortgage loan / Lith. hipotekinés paskola (ETŽ 104), etc.

The first example illustrating this group is Eng. gross profit / Lith. bendrasis pelnas:

A 1 ₹ B 1 (A 1 - a company's profit, B 1 - difference between sales revenue and cost).

The term 'gross profit' is defined as 'a company's profit before certain costs and taxes are taken away' (1-e-DIC). Dictionary of Economic Terms describes the term 'bendrasis pelnas' as 'skirtumas tarp pardavimo pajamų ir savikainos. Skaičiuojant bendraji pelnq, dažniausiai iskaitomi įmonés mokesčiai ir nusidévejjimas' (ETŽ 43). The English term accentuates 'gross profit' as company's profit pre-tax, in contrast Lithuanian term emphasizes 'the difference between sales revenue and cost. Company taxes and depreciation are usually included when calculating gross profit'. Thus, this term is surrogate as the term concepts convey different meanings.

Another example ascribed to this group is Eng. net value / Lith. grynoji verté: 
A 1 ₹ B 1 (A 1 - the amount of rent, B 1 - the acquisition (creation, increase) value of the investment; the value of the financial assets of the financial institution).

Longman Dictionary of Business English describes the term as 'the amount of rent that could be charged for a house, land etc., used in Britain as a basis for calculating local taxes' (1-e-DIC). Lithuanian term 'grynoji vertè' is provided with two meanings: 1) 'investicijos ¿̇sigijimo (sukūrimo, vertès padidinimo) verté, sumažinta amortizacijos verte ir šios investicijos rizikai amortizuoti sudarytais specialiaisiais atidejiniais'; 2) 'finansu įstaigos finansinio turto vertè, ikkainota rinkos kaina arba įsigijimo kaina, sumažinta šiam turtui sudarytais specialiaisiais atidejiniais' (ETŽ 101). Neither of those meanings corresponds to the English word concept.

One more example belonging to this group is Eng. cash balance / Lith. grynuju pinigu atsarga:

A 1 ₹ B 1 (A 1 - the amount of money a company has; B1 - the amount of money an individual wishes to have on a permanent basis).

This term can be considered as the case of surrogate equivalence since the main concept of the term does not coincide, whereas additional properties are the same, e. g. the term 'cash balance' is described as 'the amount of money a company has in its bank accounts' (1-e-DIC). Lithuanian term 'grynuju pinigu atsarga' is defined as 'pinigu suma, kuriq individas pageidauja nuolat turèti grynujų pinigu pavidalu' (ETŽ 101). The difference in meaning is illustrated by the verb 'has' in English definition and 'wishes to have' in Lithuanian.

\section{Eng. prestige/goodwill / Lith. prestižas:}

A 1 ₹ B 1 (A 1 - the respect and importance a person, etc.; B1 - the amount of money). Longman Dictionary of Business English explains the term as 'the respect and importance a person, organization, profession, or product has because of their success and high quality' (1-e-DIC), whereas Lithuanian dictionary defines the term as 'suma, kuria pirkejjo už įmonès akcijas sumokèta kaina viršija isigytos įmonés grynojo turto vertę' (ETŽ 225) which in English means the amount by which the price paid by the purchaser for the company's shares exceeds the net asset value of the acquired company. The term is surrogate since English and Lithuanian concepts convey different meanings.

Eng. negative income tax / Lith. neigiamasis pajamu mokestis:

A 1 ₹ B 1 (A 1 - a proposal, B1- social benefits).

The term 'negative income tax' is given the following definition by Longman Dictionary of Business English: 'a proposal by some economists and politicians to make payments to people on low wages to bring their incomes up to a minimum level' (1-e-DIC). However, Lithuanian definition 'socialinès išmokos iš valstybès biudžeto, mokamos, kai asmens gaunamos pajamos neviršija tam tikros nustatytos sumos' (ETŽ 183) in R. Vainienè's dictionary emphasizes the fact of social benefit itself from the state budget that is paid to a person whose income does not exceed a certain fixed amount.

Eng. tax base / Lith. mokesčio bazé:

A 1 ₹ B 1 (A 1 - all the people who pay tax, B 1 - taxed amount).

Longman Dictionary of Business English determines the term as 'all the people who pay tax, and the total amount that they pay' (1-e-DIC). Yet, Lithuanian term definition presented in R. Vainienè's dictionary 'suma, nuo kurios apskaičiuojami mokesčiai. Mokesčio bazę apibréžia taisykliu visuma' (ETŽ 171) conveys a different meaning, it clarifies and describes the term as the amount from which taxes are calculated and the tax base is defined by a set of rules. 
The aforementioned examples illustrate differences in meanings in both dictionaries, they are interpreted or paraphrased with no equivalence to each other. Thus, it makes it very problematic for researchers or translators to convey the proper meaning of the term.

2 Partial equivalents. The meaning of the term is partially explained, some meanings are expanded.

Further analysis of the terms identified $42 \%$ of the terms representing partial equivalents. The following examples were included and analysed in the study: Eng. share capital / Lith. akciju kapitalas (ETŽ 18), Eng. royalty / Lith. autorinis atlyginimas (ETŽ 38), Eng. excise tax / Lith. akcizas (ETŽ 19), Eng. paid-in capital / Lith. apmokètasis kapitalas (ETŽ 27), Eng. cash / Lith. grynieji pinigai (ETŽ 101), Eng. debit card / Lith. debeto kortele (ETŽ 61), etc.

Various types of partial equivalents can be distinguished and subdivided into four subgroups.

\subsection{Not all concept properties coincide $(A=B ; A \neq B)$}

This subgroup consists of the terms some properties of which coincide, and some do not. The following are the examples of this group: Eng. deposit / Lith. indélis (ETŽ 108), Eng. tax base / Lith. mokesčio bazè (ETŽ 171), Eng. tax overpayment / Lith. mokesčio permoka (ETŽ 173), Eng. retained/undistributed profit / Lith. nepaskirstytasis pelnas (ETŽ 186), Eng. indirect taxes / Lith. netiesioginiai mokesčiai (ETŽ 188), etc.

Eng. share capital / Lith. akcijų kapitalas:

A 1 = B 1 (capital that a company has);

A 2 = B 2 (from investors);

A 3 ₹ B 3 (A 3 - have bought shares, B 3 - issued shares).

The term 'share capital' in Longman Dictionary of Business English is referred to as 'capital that a company has from investors who have bought shares' (1-e-DIC). Its Lithuanian equivalent 'akciju kapitalas' is described as 'akcininku nuosavybes dalis, suformuota išleidžiant akcijas' (ETŽ 18). Apart from two equal concept properties the term possesses one more attribute which is defined differently in English and Lithuanian dictionaries. According to English definition, 'share capital' is obtained from investors who 'have bought shares' and Lithuanian definition emphasizes the share of shareholders' equity formed 'by issuing shares'.

Eng. royalty / Lith. autorinis atlyginimas:

A 1 = B 1 (payment);

A 2 = B 2 (made to someone);

A 3 \# B 3 (A 3 - who owns a copyright or a patent, B 3 - for the creation and / or performance and / or transfer of the work).

One more example representing this group is the term 'royalty' which is characterized as 'a payment made to someone who owns a copyright or a patent (=legal right to be the only producer or seller of something), for example an inventor or the writer of a book' (1-eDIC). The Lithuanian term 'autorinis atlyginimas' means 'autoriui už kūrinio sukūrimą ir / ar atlikima ir/ar perdavima sumoketas atlyginimas' (ETŽ 38). English term is expanded by adding the concept property 'someone who owns a copyright or a patent', and Lithuanian term highlights a payment 'for the creation and/or performance and / or transfer of the work'.

\subsection{Both languages have additional properties $(\mathrm{A}<\mathrm{B} ; \mathrm{A}>\mathrm{B})$}

Terms which in both languages have additional meanings belong to this subgroup. The examples are as follow: Eng. minimum wage / Lith. minimalus darbo užmokestis (ETŽ 168), 
Eng. real estate tax / Lith. nekilnojamojo turto mokestis (ETŽ 184), Eng. endowment / Lith. dovanotasis kapitalas (ETŽ 70), etc.

Eng. excise tax / Lith. akcizas:

A 1 = B 1 (a tax on certain goods);

A $2>$ B 2 (produced);

A $3<$ B 3 (expressed in a percentage of the price of the good or in the absolute amount);

A $4<$ B 4 (to the state budget);

A $\mathbf{5}=\mathbf{B} \mathbf{5}$ (sold in a country).

The term 'excise tax' is defined as 'a tax on certain goods produced and sold in a country, for example cigarettes and alcoholic drinks' (1-e-DIC). Lithuanian term 'akcizas' means ' $i$ valstybès biudžeta mokamas vartojimo mokestis, išreikštas procentais nuo prekés kainos arba absoliučia suma ir pridedamas prie parduodamos prekès kainos' (ETŽ 19). Apart from two equivalent properties, English term has one more additional property characterizing 'the tax on certain goods produced', whereas Lithuanian term possesses two more extra properties pinpointing the tax 'to the state budget that is expressed in a percentage of the price of the good or in the absolute amount'.

Eng. advance payment / Lith. avansas:

A 1 = B 1 (payment);

A 2 = B 2 (made before);

A $3>$ B 3 (a product is delivered, or a piece of work is completed);

A $4<$ B 4 (in the contract).

Another example representing this subgroup is 'advance payment'. Longman Dictionary of Business English explains the term as 'a payment made before a product is delivered or a piece of work is completed' (1-e-DIC). Lithuanian dictionary describes the term 'avansas' as 'sutartyje numatytos sumos ar jos dalies išankstinis sumokejjimas' (ETŽ 38). Two concept properties of the word coincide, others are expanded both in English and Lithuanian languages.

\subsection{English concept has more properties than the Lithuanian one (A > B)}

Terms which have more concept properties in English than in Lithuanian belong to the third subgroup, e.g. Eng. paid-in capital / Lith. apmokètasis kapitalas (ETŽ 27), Eng. cash / Lith. grynieji pinigai (ETŽ 101), Eng. annuity / Lith. anuitetas (ETŽ 24), Eng. arbitrage / Lith. arbitražas (ETŽ 29), Eng. gross income / Lith. bendrosios pajamos (ETŽ 47), etc.

Eng. paid-in capital / Lith. apmokètasis kapitalas:

A 1 = B 1 (share capital);

A 2 = B 2 (for which money has actually been received);

A 3 > B 3 (from shareholders).

The term 'paid-in capital' has a meaning of 'share capital for which money has actually been received from shareholders, rather than for shares not yet paid for or not yet issued (=made available)' (1-e-DIC). Lithuanian term 'apmoketasis kapitalas' is given the following definition: 'įstatinio kapitalo dalis, už kuriq jau yra sumokèta' (ETŽ 27). Two properties of the term coincide. However, the term 'paid-in capital' is provided with one additional property - 'money ... received from shareholders'.

Eng. cash / Lith. grynieji pinigai:

A 1 = B 1 (money in the form of notes and coins);

A 2 > B 2 (rather than cheques, credit cards etc.).

One more example representing this subgroup of partial equivalence is the term 'cash' which is defined as 'money in the form of notes and coins, rather than cheques, credit cards, etc.' (1-e-DIC). R.Vainienè's 'Dictionary of Economic Terms' describes the word 'grynieji 
pinigai' as 'monetos ir popieriniai pinigai' (ETŽ 101). English term possesses one extra attribute expliciting on 'money rather than cheques, credit cards, etc.'.

\subsection{Lithuanian concept has more properties than the English one $(\mathrm{A}<\mathrm{B})$}

Terms that have more properties in the Lithuanian language in comparison to English belong to that subgroup. These are the examples: Eng. capital gains tax / Lith. kapitalo prieaugio mokestis (ETŽ 128), Eng. withholding tax / Lith. mokestis prie šaltinio (ETŽ 176), Eng. debit card / Lith. debeto kortele (ETŽ 61), etc.

Eng. debit card / Lith. debeto kortelé:

A 1 = B 1 (a plastic card);

A 2 = B 2 (to pay for goods and services);

A 3 = B 3 (from the user's bank account);

A $4<$ B 4 (withdraw cash from an ATM).

The term 'debit card' in Longman Dictionary of Business English is referred to as ' $a$ plastic card which is used instead of money or a cheque to pay for goods and services. The cost is taken directly from the user's bank account' (1-e-DIC). Lithuanian term 'debeto kortelè' is characterised as 'banko išduota atsiskaitymo kortelè, kurios sq̨skaitoje privalo būti pakankamas lèšų likutis tam, kad kortele būtų galima atsiskaityti už prekes ir paslaugas arba išsiimti grynuju pinigu iš bankomato' (ETŽ 61). Three concept properties coincide in both languages, whereas Lithuanian term 'debeto kortele' is provided with one additional property that highlights possibility 'to withdraw cash from an ATM'.

Eng. budget / Lith. biudžetas:

A 1 = B 1 (a detailed plan);

A 2 = B 2 (of how much it will receive as income and how much it will spend);

A 3 = B 3 (an organization or a government);

A 4 < B 4 (budgets of central government, municipalities, state social insurance fund, etc.).

One more example attributed to this subgroup is 'budget' which has the following definition: 'a detailed plan made by an organization or a government of how much it will receive as income over a particular period of time, and how much it will spend, what it will spend the money on etc.' (1-e-DIC). Lithuanian term 'biudžetas' is explained as 'pajamu ir išlaidu sąmata. Sąvoka labai dažnai vartojama kalbant apie valstybés pajamas ir išlaidas. Lietuvoje sudaromi ir tvirtinami centrines valdžios, savivaldybiu, valstybinio socialinio draudimo fondo ir kt. biudžetai' (ETŽ 49). From the above example it can be seen that this term is considered to be partially equivalent as three concept properties coincide. Yet, the Lithuanian term meaning is expanded with additional attribute, namely that 'in Lithuania, budgets of the state social insurance fund, the central government, municipalities, etc. are formed and approved'.

This group of terms is the most abundant. The above analysed cases of partial equivalence of terms demonstrate a diversity of term meanings. According to the research, some concept properties are not equivalent, some are extended or narrowed either in Lithuanian or English. However, the most important aspect is the equivalence of the main concept which is crucial in proper perception of the term meaning.

\section{Absolute equivalence. All the concept properties coincide $(A=B)$}

$37 \%$ of the terms ascribed to the third group represent the cases of absolute equivalence and the examples are as follow: Eng. turnover / Lith. apyvarta (ETŽ 26), Eng. taxable income / Lith. apmokestinamos pajamos (ETŽ 26), Eng. penalty / Lith. bauda (ETŽ 
45), Eng. gross income / Lith. bendrosios pajamos (ETŽ 47); Eng. dividends / Lith. dividendai (ETŽ 68), etc.

The instances of this group are not further discussed in more detail as their meanings are consistent in both English and Lithuanian languages and their explicit explanations are not further presented.

\section{Conclusions}

Having analysed concept descriptions of the semantic economic term group related to finance in English and Lithuanian, it was determined that the majority of terms (37\%) are equivalent, i. e. the concepts are conforming in the system of concepts and perform the same function. Most frequently, these are the terms having old traditions in both languages, e.g. Eng. penalty / Lith. bauda, Eng. net expert / Lith. grynasis eksportas, etc.

The terms whose main properties coincide in both languages make up the most abundant group (42\%). However, without conforming attributes partial equivalents possess extra information defining the term meaning, e.g. Eng. excise tax / Lith. akcizas, Eng. advance payment / avansas. Introduction of additional properties to the concepts is characteristic to both, English and Lithuanian languages. Comparison of the cases of extension or narrowing of term meanings has led to an assumption that the meaning of a partially equivalent term is most frequently conveyed by expanded word combinations which reveal the main properties of the concept in the Lithuanian language rather than in English. The examples are as follow: Eng. minimum wage / Lith. minimalus darbo užmokestis, Eng. real estate tax / nekilnojamo turto mokestis, etc.

Not only does this research reveal the cases of equivalents' absence but also explanations of totally different concept definitions. $21 \%$ of the analysed financial terms are included into the group whose definitions did not coincide with the main properties of the concepts, e.g. Eng. tax overpayment / Lith. mokesčio permoka, Eng. retained/undistributed profit / nepaskirstytasis pelnas, etc. Such diverse perception and explanation of terms of both languages in the process of communication often cause confusion and misunderstandings.

In conclusion, it is possible to state that the equivalent property comparison of the researched financial terms remains relevant as it unveils the peculiarities of the concept of linguistic culture. It also has applied value in the areas of language teaching, translation practice, and intercultural communication.

This research shows that term expression, perception and unification is crucial both in communication situations and business context. It is highly important that concept properties convey the same meaning which facilitates the work for translators, linguists, researchers, etc.

\section{References}

Armalytė, O., Pažūsis, L. (1990). Vertimo teorijos pradmenys. Vilnius: Vilniaus universiteto leidykla.

Arntz, R., Picht, H., Mayer, F. (2004). Einführung in die Terminologiearbeit (p. 152). Hildesheim, Zürich, New York.

Buhlmann, R. Fearns, A. (2000). Handbuch des Fachsprachenunterrichts (p. 33). Verlag Tübingen.

Falkum, I., L., Vicente, A. (2015). Polysemy: Current Perspectives and Approaches. Available at: https://www.researchgate.net/publication/272740167_Polysemy_Current_ perspectives_and_approaches.

Gudavičius, A. (2007). Gretinamoji semantika. (p. 244). Šiauliai. 
Jackson, H., Ze Amvela, E. (2014). Word, Meaning and Vocabulary. (p. 69). London.

Jackson, H. (2002). Lexicography. An Introduction. (p. 141). Taylor \& Francis Routledge.

Jakaitienè, E. (2005). Leksikografija. (p. 324). Vilnius: Mokslo ir enciklopedijų leidybos institutas.

Jakaitienè, E. (2010). Lietuviu kalbos leksikologija. (p. 351). Vilnius: Mokslas.

Keinys, S. (2005). Dabartiné lietuvių terminologija. (p. 500). Vilnius: LKI.

Kontutytè, E. (2008). Imonių teisinés formos: vokišku ir lietuviškų terminu ekvivalentiškumo problemos. Kalbotyra. T. 58(3), (p. 69-79). Available at: http://www.kalbotyra.flf.vu.lt/wp-content/uploads/2011/12/Kalbotyra_58_6979.pdf.

LST ISO 1087-1: 2005. Terminologijos darbas. Aiškinamasis žodynas. 1 dalis. Teorija ir taikymas (equivalent ISO 1087-1: 2000).

Martinkus, B. et al (2000). Aiškinamasis įmonés vadybos terminų žodynas. KTU leidykla Technologija.

Maskaliūnienè, N. (2015). Apskaitos terminų žodynas mašininiam žodynui. Vilnius: Vilniaus Universitetas.

Nordisk. (1997). Nordisk lekskografisk ordbok. (p. 253). Oslo: Universitetforlaget.

Pearce, D. W. (2006). Aiškinamasis ekonomikos anglų-lietuvių kalbų žodynas. Macmillan.

Procter, P. Longman Dictionary of Business English of Online 5th Edition. Managing editor Bullon, S. et. al. 1978. Pearson ELT. Available at: www.ldoceonline.1978. [Accessed 20 February 2020]; [1-e-DIC].

Sterkenburg, P. V. (2003). A Practical Guide to Lexicography. Edited by Piet Van Sterkenburg. (p. 85-87, 141, 267). Leiden, Amsterdam/Philadelphia: Institute for Dutch Lexicology.

Tadauskienė, E. (2006). Ekonomikos ir informatikos terminijos informatyvumas. Vilniaus Universitetas. Available

at: http://elibrary.lt/resursai/Mokslai/VGTU/Santalka/2006/4/10.pdf ).

Terminologijos vadovélis Europos komisijos vertimo raštu generalinio direktorato lietuviu kalbos departamento vertejjams. (2006). Liuksemburgas. Available at: http://ec.europa.eu/translation/lithuanian/ltf/documents/ltf_translation_terminolo gy_lt.pdf.

Vainienè, R. (2005). Ekonomikos terminu žodynas. Vilnius: Tyto Alba.

Vogel, R. (2008). Synonymy and Polysemy in Accounting Terminology: Fighting to Avoid Inaccuracy. SKASE Journal of Translation and Interpretation. Vol. 3, No. 1. Available at: http://w.skase.sk/Volumes/JTI03/pdf_doc/Vogel.pdf.

\section{Contact}

Daiva Zavistanavičienè

Faculty of Social Sciences, Humanities and Arts

Kaunas University of Technology

Mickevičiaus g. 37-1309

Kaunas, LT 44244, Lithuania

daiva.zavistanaviciene@ktu.lt 